\title{
Evaluation of the Elbow Carrying Angle in Healthy Individuals
}

\author{
Evaluación del Ángulo de Desplazamiento del Codo en Individuos Sanos
}

Ahmet Kürsad Açıkgöz; Raciha Sinem Balci; Pınar Göker \& Memduha Gülhal Bozkir

AÇIKGÖZ, A. K.; BALCI, R. S.; GÖKER, P. \& BOZKIR, M. G. Evaluation of the elbow carrying angle in healthy individuals. Int. J. Morphol., 36(1):135-139, 2018.

SUMMARY: Carrying angle, or cubital angle defined as the acute angle formed by the median axis of the arm when forearm is in fully extended and supinated position. This angle changes with skelatal growth and maturity. This study was aimed to investigate the correlation of carrying angle with bi-acromial diameter and bi-acromial diameter/bi-trochanteric diameter in our healthy young adult population. This was a cross-sectional study that included 400 (204 male,196 female) young adult students selected from Çukurova University aged between 18-25 years (mean \pm standard deviation of females: $20.11 \pm 2.05$ years; mean \pm standard deviation of males: $20.45 \pm 1.82$ years) which originated from different cities in Turkey. After recording demographic data, carrying angle, forearm length, arm length, bi-trochanteric diameter and bi-acromial diameter were measured by using nonelastic tape measure, pelvimeter and manuel goniometer. In addition, body mass index and bi-acromial diameter/bi-trochanteric diameter were calculated for each participants. The mean values of body height and weight were in following respectively for both genders: $178.53 \pm 6.40 \mathrm{~cm}(\mathrm{male}), 163.88 \pm 5.73 \mathrm{~cm}$ (female); $74.89 \pm 10.81 \mathrm{~kg}$ (male), $57.56 \pm 8.61 \mathrm{~kg}$ (female). Whereas on dominant arm this angle was as in males $9.77^{\circ} \pm 2.82^{\circ}$ and $13.94^{\circ} \pm 3.97^{\circ}$ in females. The mean value of the carrying angle on nondominant arm in males was $9.85^{\circ} \pm 2.95^{\circ}$ and $14.03^{\circ} \pm 4.08^{\circ}$ in females. The mean carrying angle was $9.81^{\circ} \pm 2.82^{\circ}$ in males and $13.99^{\circ} \pm 3.97^{\circ}$ in females. There are linear relationship between the carrying angle and height $(r=-0.474, p<0.001$, bi-acromial diameter $(r=-0.490, p<0.001)$, bi-acromial diameter/bi-trochanteric diameter $(r=-0.449, p<0.001)$, forearm length $(\mathrm{r}=-0.366, \mathrm{p}<0.001)$ and arm length $(\mathrm{r}=-0.273$, $\mathrm{p}<0.001)$. We believe that the reference values of carrying angle will help the clinician in the management of elbow displacements, fractures, prosthetic design and diagnosis of epicondylar diseases.

KEY WORDS: Carrying angle; Elbow joint; Bi-acromial diameter/bi-trochanteric diameter; Forearm length; Arm length.

\section{INTRODUCTION}

The elbow joint, which is the complex structure provides mechanical link in the upper limb between the hand, wrist and the shoulder. Moreover, it acts as a hinge point for the forearm for powerful grasping and fine motor motions of the hand (Zampagni et al., 2008; Hassan et al., 2014). This paper was focused on the angle between the arm and the forearm defined as carrying angle (Zampagni et al., 2008; Paraskevas et al., 2004; Van Roy et al., 2005). Carrying angle or cubital angle defined as the acute angle formed by the median axis of the arm when forearm is in fully extended and supinated position (Paraskevas et al., 2004; Ruparelia et al., 2010). This angle is observed best when the shoulder is in external rotation, the elbow is in full extention and the forearm is in supination (Hassan et al., 2014; Zampagni et al., 2008). This angle is $155-180^{\circ}$ or $0-25^{\circ}$ by the mean of supplementary angle (Paraskevas et al., 2004).

Carrying angle especially helps in keeping the forearm away from pelvis when the upper limb swing during walking and is significant for holding objects (Srivastava \& Solanki,
2015; Chang et al., 2008; Lim et al., 2014). Increasing of carrying angle may cause instability in elbow joint and pain during exercises and throwing sport activities (Lim et al., 2014). Data of the mean values of carrying angle helps to evaluate the aesthetically acceptiblity level of arm and forearm deformity (Balasubramanian et al., 2006). It is reported that knowledge of carrying angle values and pathological variations are important for especially ulnar nerve problems, elbow fractures and diagnosis of lateral or medial epicondylitis (Zampagni et al., 2008; Balasubramanian et al., 2006). Furthermore, besides its ergonomic significance, carrying angle is also necessary for especially orthopedic approaches, manual therapy and reconstruction of carrying angle in elbow implantation operations (Van Roy et al., 2005).

Therefore, this study was aimed to investigate the correlation of carrying angle with bi-acromial diameter and bi-acromial diameter/bi-trochanteric diameter in our healthy young adult population due to sexes and compare them to other populations.

Department of Anatomy, Faculty of Medicine, Çukurova University, Adana, Turkey. 


\section{MATERIAL AND METHOD}

The research protocol of this study was approved by the ethics committee of the School of Medicine, Çukurova University. Informed consent form was obtained from all participants before measurements. This was a cross-sectional study that included 400 (204 male, 196 female) young adult students selected from Çukurova University aged between 18-25 years (mean \pm standard deviation of females: $20.11 \pm 2.05$ years; mean \pm standard deviation of males: $20.45 \pm 1.82$ years) which originated from different cities in Turkey. Inclusion criteria were no history of trauma or fractures in the upper limb. After recording demographic data, anthropometric measurements were performed by using nonelastic tape measure, pelvimeter and manuel goniometer. Body weight was measured with electronic scales to the nearest $0.1 \mathrm{~kg}$ wearing minimal clothing without shoes and height was measured to the nearest milimeter in bare foot with a wall-mounted stadiometer. Also body mass index (BMI; in $\left.\mathrm{kg} / \mathrm{m}^{2}\right)$ was calculated.

Five anthropometric measurements were as follows.

- The elbow carrying angle (Fig. 1)

Pivot point: Fossa cubitalis

Fixed arm: Sulcus intertubercularis

Swinging arm: A line on tendon of $\mathrm{m}$. palmaris longus, to the wrist.

- Forearm length: Distance between epicondylus medialis and processus styloideus ulnae

- Arm length: Distance between acromion and epicondylus lateralis

- Bi-trochanteric diameter: Distance between most lateral projection of the greater trochanters

- Bi-acromial diameter: Distance between most lateral projections of the acromial processes

The data were analyzed using SPSS 22.0 programme. The association of bi-trochanteric diameter, bi-acromial diameter, bi-acromial diameter/bitrochanteric diameter, height, forearm length, arm length and body mass index (BMI) with carrying angle were analyzed by using Pearson's correlation test. Differences between dominant and nondominant arm and between sexes were analyzed by independent sample t-test and $p<0.05$ was accepted as the level of significance.

\section{RESULTS}

Measurements were obtained from 400 young adult participants and mean age, body height and body weight were shown in Table I.

Carrying angle measurements were obtained from 800 arms (400 right, 400 left). The mean carrying angle on dominant arm in males was $9.77^{\circ} \pm 2.82^{\circ}$ and $13.94^{\circ} \pm 3.97^{\circ}$ in females while on nondominant arm same value was in males $9.85^{\circ} \pm 2.95^{\circ}$ and $14.03^{\circ} \pm 4.08^{\circ}$ in females. Statistically significant differences were not found between dominant and nondominant arm by carrying angle in males and females ( $p>0.05$ ). In addition, the mean carrying angle was $9.81^{\circ} \pm 2.82^{\circ}$ in males and $13.99^{\circ} \pm 3.97^{\circ}$ in females. There were statistically significant differences were

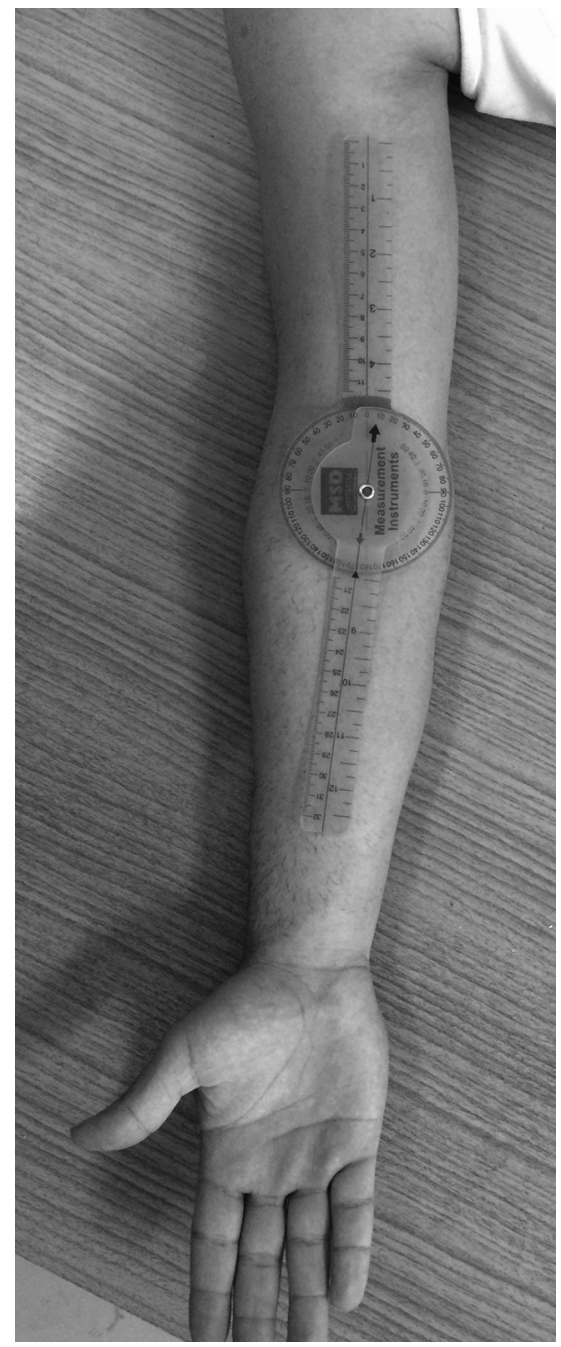

Fig. 1. Showing the measurement of the carrying angle

found between sexes in dominant and nondominant arm $(\mathrm{p}<0.001)$ (Table II).

There are inverse relationships $(\mathrm{r}=-0.474, \mathrm{p}<0.001)$ between the carrying angle and height. At the same time, biacromial diameter $(\mathrm{r}=-0.490, \mathrm{p}<0.001)$, bi-acromial diameter/bi-trochanteric diameter $(\mathrm{r}=-0.449, \mathrm{p}<0.001)$, forearm length $(r=-0.366, p<0.001)$ and arm length $(\mathrm{r}=-0.273, \mathrm{p}<0.001)$ have inverse correlation with the carrying angle of the elbow. However, there were no correlation between bi-trochanteric diameter and BMI with carrying angle of the elbow (Table III). 
Table I. Mean measurements of height, body weight and age in males and females.

\begin{tabular}{lccc}
\hline \multicolumn{4}{c}{ Measurements } \\
\hline Male & Height $(\mathrm{cm})$ Mean \pm SD & Weight $(\mathrm{kg})$ Mean \pm SD & Age (years) Mean \pm SD \\
Female & $178.53 \pm 6.40$ & $74.899 \pm 10.81$ & $20.45 \pm 1.82$ \\
& $163.88 \pm 5.73$ & $57.561 \pm 8.61$ & $20.11 \pm 2.05$ \\
\hline
\end{tabular}

Table II. Average angle values according to sex and dominance of the limb.

\begin{tabular}{lccc}
\hline & Dominant Arm (degrees) & Nondominant Arm (degrees) & P value \\
\cline { 2 - 4 } & Mean \pm SD & Mean \pm SD & \\
\hline Male & $9.77^{\circ} \pm 2.82^{\circ}$ & $9.85^{\circ} \pm 2.95^{\circ}$ & $\mathrm{p}=0.788$ \\
Female & $13.94^{\circ} \pm 3.97^{\circ}$ & $14.03^{\circ} \pm 4.08^{\circ}$ & $\mathrm{p}=0.837$ \\
P value & $\mathrm{p}<0.001$ & $\mathrm{p}<0.001$ & \\
\hline
\end{tabular}

Table III. Pearson's correlation coefficient (r) relating carrying angle and anthropometric parameters.

\begin{tabular}{lcc}
\hline & Pearson's correlation coefficient $(\mathrm{r})$ & $\mathrm{P}$ \\
\hline eight & $\mathrm{r}=-0.474$ & $\mathrm{p}<0.001$ \\
i-acromial Diameter & $\mathrm{r}=-0.490$ & $\mathrm{p}<0.001$ \\
i-trochanteric Diameter & $\mathrm{r}=-0.075$ & $\mathrm{p}=0.134$ \\
i-acromial Diameter/Bi-trochanteric Diameter & $\mathrm{r}=-0.449$ & \\
orearm Length & $\mathrm{r}=-0.366$ & $\mathrm{p}<0.001$ \\
rm Length & $\mathrm{r}=-0.273$ & $\mathrm{p}<0.001$ \\
ody Mass Index & $\mathrm{r}=-0.079$ & $\mathrm{p}=0.115$ \\
\hline
\end{tabular}

\section{DISCUSSION}

Posture is the proportional alignment of the body segments with one another. Having a good posture means balanced body alignment and minimal applied stress on various body segments (Hassan et al., 2014). Conversely poor posture causes unbalanced body alignment because of the stress on body segments. With the passing of time, this continual stress causes anatomical adaptation even though body segments are exposed to this at low levels. Because of these changes, individual's ability to perform and overall efficiency is affected (Hassan et al., 2014). The elbow joint, which is the complex structure provides mechanical link in the upper limb between the hand, wrist and the shoulder. Our concern is carrying angle, which is described as angle between the arm and forearm in the frontal plane and has an important role on carrying loads (Zampagni et al., 2008; Hassan et al., 2014). The mean carrying angle was found $166.64^{\circ}$ (supplementary angle:13.36) among 11 subjects by Braune \& Kyrklund (1879) who first described carrying angle (Paraskevas et al., 2004; Braune \& Kyrklund, 1879). It was claimed that in a study which focused on estimation of carrying angle based on CT images for surgical planning was showed that mean carrying angle was as $16.3^{\circ} \pm 3.21^{\circ}$ (Park \& Kim, 2009). Moreover, the mean carrying angle values and range of normality was determined according to age in some studies (Terra et al., 2011; Dey et al., 2013). It was estimated that the differences between sexes for carrying angle were not statistically significant in radiographs (Kumar et al., 2010). Allouh et al., provided information to the literature by studying race-dependent variations and in terms of effects of the sex and handedness on the carrying angle (Allouh et al., 2016). A study which performed in 88 upper limbs showed differences in carrying angle according to sex, age, race (Paraskevas et al., 2004; Mall, 1905). However, it was reported that there were no differences in carrying angle according to sex and age on right elbow (Emami et al., 1998).

In addition, a study about variations of carrying angle according to age, sex and dominancy in 275 healthy volunteers reported that in the right arm dominant group, right carrying angle was $11.25^{\circ} \pm 3.73^{\circ}$ and left carrying angle was $10.57^{\circ} \pm 3.63^{\circ}$ while in the left arm dominant group, right carrying angle was $10.65^{\circ} \pm 3.99^{\circ}$ and left carrying angle was $12.93^{\circ} \pm 4.22^{\circ}$ (Y1lmaz et al., 2005). They emphasized that mean carrying angle value was significantly greater in dominant arm than the nondominant arm in both sexes (Y1lmaz et al., 2005). Conversely, it was evaluated that this angle among children was greater in nondominant limbs than dominant limbs (Sharma et al., 2015). And also it was reported that the mean values of the carrying angle on right arm was $19.4^{\circ}$ and on the left arm was $12.8^{\circ}$ in males whereas on right arm was $21.2^{\circ}$ and on left arm was $18.4^{\circ}$ in females (Baskar \& Kumar, 2013). It was noted that the angle varies 
Table IV. Carrying angle measurements in various groups.

\begin{tabular}{|c|c|c|c|c|c|c|}
\hline $\begin{array}{l}\text { Paraskevas } \\
\text { et al., } 2004 .\end{array}$ & Greece & $\begin{array}{l}600 \text { ( } 280 \text { female, } \\
320 \text { male) }\end{array}$ & \multicolumn{2}{|c|}{$15.07^{\circ} \pm 4.95^{\circ}$} & \multicolumn{2}{|c|}{$10.97^{\circ} \pm 4.27^{\circ}$} \\
\hline Potter, 1895 & N/A & $\begin{array}{l}185 \text { (90 female, } \\
95 \text { male) }\end{array}$ & \multicolumn{2}{|c|}{$12.65^{\circ}$} & \multicolumn{2}{|c|}{$6.83^{\circ}$} \\
\hline $\begin{array}{l}\text { Atkinson \& } \\
\text { Elftman, } \\
1945 \text {. }\end{array}$ & $\begin{array}{l}\text { America } \\
\text { (Columbia } \\
\text { University) }\end{array}$ & $\begin{array}{l}217 \text { ( } 112 \text { female, } \\
105 \text { male) }\end{array}$ & \multicolumn{2}{|c|}{$16.2^{\circ} \pm 0.5^{\circ}$} & \multicolumn{2}{|c|}{$14.4^{\circ} \pm 0.5^{\circ}$} \\
\hline $\begin{array}{l}\text { Ruparelia et } \\
\text { al., } 2010\end{array}$ & Gujarat (India) & $\begin{array}{l}333 \text { (173 female, } \\
160 \text { male) }\end{array}$ & \multicolumn{2}{|c|}{$11.8^{\circ}$} & \multicolumn{2}{|c|}{$6.9^{\circ}$} \\
\hline \multirow{2}{*}{$\begin{array}{l}\text { Kothapalli } \\
\text { et al., } 2013 . \\
\text { Srivastava } \\
\text { \& Solanki, } \\
2015 .\end{array}$} & $\begin{array}{l}\text { Karnataka } \\
\text { (India) }\end{array}$ & $\begin{array}{l}220 \text { (110 female, } \\
110 \text { male })\end{array}$ & $\begin{array}{c}13.54^{\circ} \pm 6.44^{\circ} \\
\text { (right arm) }\end{array}$ & $\begin{array}{c}11.90^{\circ} \pm 5.61^{\circ} \\
(\text { left arm })\end{array}$ & $\begin{array}{c}12.09^{\circ} \pm 4.66^{\circ} \\
\text { (rigth arm) }\end{array}$ & $\begin{array}{l}11.20^{\circ} \pm 4.53 \\
\circ \quad(\text { left arm })\end{array}$ \\
\hline & $\begin{array}{l}\text { Moradabad } \\
\text { (India) }\end{array}$ & 250 & $\begin{array}{c}14.80 \pm 2.31^{\circ} \text { (right } \\
\operatorname{arm})\end{array}$ & $\begin{array}{c}14.27 \pm 2.65^{\circ} \\
(1 \mathrm{eft} \text { arm })\end{array}$ & $\begin{array}{l}11.21 \pm 2.63^{\circ} \\
\text { (right arm) }\end{array}$ & $\begin{array}{c}10.69 \pm 2.86^{\circ} \\
(\text { left arm) }\end{array}$ \\
\hline \multirow[b]{2}{*}{$\begin{array}{l}\text { Allouh et } \\
\text { al., } 2016 .\end{array}$} & Arab & $\begin{array}{l}457 \text { ( } 204 \text { female, } \\
253 \text { male) }\end{array}$ & $\begin{array}{l}17.50^{\circ} \pm 0.3^{\circ} \\
\text { (right arm) }\end{array}$ & $\begin{array}{c}16.0^{\circ} \pm 0.6^{\circ} \\
(\mathrm{left} \text { arm })\end{array}$ & $\begin{array}{l}13.0^{\circ} \pm 0.2^{\circ} \\
\text { (right arm) }\end{array}$ & $\begin{array}{c}10.4^{\circ} \pm 0.2^{\circ} \\
(\mathrm{left} \text { arm })\end{array}$ \\
\hline & Malay & $\begin{array}{l}345(162 \\
\text { female, } 183 \\
\text { male) }\end{array}$ & $\begin{array}{c}15.7^{\circ} \pm 0.4 \text { (right } \\
\text { arm) }\end{array}$ & $\begin{array}{l}14.3^{\circ} \pm 0.3 \\
(\mathrm{left} \text { arm })\end{array}$ & $\begin{array}{c}14.1^{\circ} \pm 0.2 \\
\text { (right arm) }\end{array}$ & $\begin{array}{c}12.5^{\circ} \pm 0.2 \\
(\text { left arm })\end{array}$ \\
\hline $\begin{array}{l}\text { Present } \\
\text { Study }\end{array}$ & Turkey & $\begin{array}{l}400 \text { ( } 200 \text { female, } \\
200 \text { male })\end{array}$ & \multicolumn{2}{|c|}{$13.99^{\circ} \pm 3.97^{\circ}$} & \multicolumn{2}{|c|}{$9.81^{\circ} \pm 2.82^{\circ}$} \\
\hline
\end{tabular}

with age in both sexes (Paraskevas et al., 2004). When we analyzed the literature findings, the mean values of carrying angle were found between $6.7^{\circ}$ and $20^{\circ}$ in males and between $11^{\circ}$ and $25^{\circ}$ in females (Paraskevas et al., 2004; Allouh et al., 2016; Ruparelia et al., 2010; Kothapalli et al., 2013; Baskar \& Kumar, 2013; Zampagni et al., 2008; Van Roy et al., 2005; Atkinson \& Elftman, 1945 Srivastava\&Solanki, 2015; Lim et al., 2014; Potter, 1895; Rajesh et al., 2013; Sönmez et al., 2012) (Table IV). In this investigation, this angle was found as $9.77^{\circ} \pm 2.82^{\circ}$ in dominant side, $9.85^{\circ} \pm 2.95^{\circ}$ in nondominant side in males whereas $13.94^{\circ} \pm 3.97^{\circ}$ in dominant side and $14.03^{\circ} \pm 4.08^{\circ}$ in nondominant side in females respectively. Female carrying angle values were found higher than males. According to the literature findings, it was estimated that the carrying angle values were found statistically different in dominant and nondominant arm whereas there were no significant differences between both sides in our study. We think that these diversities may be depend on method differences, race, sex and individual variations.

It was claimed that height and forearm length are higher in males than in females (Kothapalli et al., 2013). In contrast to this, mean carrying angle is higher in females than males. It was explained that in shorter person the medial part of trochlear notch of ulna goes further away from the medial flange of trochlea, and the proximal end has to angulate in order to bring the hand in pronated position (Ruparelia et al., 2010). Moreover, an investigation emphasized that there was no relationship between carrying angle and forearm length in females whereas there were negative correlation between forearm length and carrying angle in males ( $\mathrm{r}=-0.199$ right arm, r=-0.198 left arm, p=0.003) (Kothapalli et al., 2013). Hassan et al., analyzed athletes and nonathletes groups in terms of forearm length correlation with carrying angle and they found negative correlation ( $\mathrm{r}=-0.586, \mathrm{p}=0.007$ ) (Hassan et al., 2014). Due to our correlation results, we found similar data. There were also negative correlation with forearm length and carrying angle in this paper $(\mathrm{r}=-0.366, \mathrm{p}<0.001)$.

There were several studies for carrying angle but there were not enough study about correlation of carrying angle with bi-acromial diameter, bi-acromial diameter/bi-trochanteric diameter. According to analysis of our data, bi-acromial diameter/bi-trochanteric diameter showed inversely correlation with carrying angle. Further studies are needed in this regard. In conclusion, we believe that knowledge of reference values of carrying angle will make contributions to the literature data and will be useful for the clinician in the management of elbow displacements, prosthetic design, diagnosis of epicondylitis and surgical planning for elbow reconstructions.

ACKNOWLEDGEMENTS. The study was funded by Çukurova University Scientific Research Projects (Project number: TSA-2016-7007).

AÇıKGÖZ, A. K.; BALCI, R. S.; GÖKER, P. \& BOZKIR, M. G. Evaluación del ángulo de desplazamiento del codo en individuos sanos. Int. J. Morphol., 36(1):135-139, 2018.

RESUMEN: Se estudió el ángulo de sustentación o ángulo cubital definido como el ángulo agudo formado por el eje mediano del brazo al estar en posición completamente extendido y supinado el antebrazo. Este ángulo cambia con el crecimiento esquelético y la madurez. El objetivo de este estudio fue investigar la correlación del ángulo con el diámetro biacromial y el diámetro bi-acromial / diá- 
metro bi-trocantérico en una población adulta joven y sana. Se realizó un estudio transversal que incluyó 400 (204 hombres, 196 mujeres) estudiantes adultos jóvenes seleccionados de la Universidad de Çukurova con edades comprendidas entre 18-25 años (media \pm desviación estándar de las mujeres: 20,11 $\pm 2,05$ años; media \pm desviación estándar de los hombres: 20,45 $\pm 1,82$ años) que se originaron en diferentes ciudades de Turquía. Después de registrar los datos demográficos, el ángulo de desplazamiento, la longitud del antebrazo, la longitud del brazo, el diámetro bi-trocantérico y el diámetro biacromial se midieron utilizando cinta métrica no elástica, pelvímetro y goniómetro manual. Además, se calcularon el índice de masa corporal y el diámetro bi-acromial / diámetro bi-trocantérico para cada participante. Los valores medios de la altura y el peso corporal fueron respectivamente para ambos sexos: 178,53 \pm 6,40 cm (masculino), $163,88 \pm 5,73 \mathrm{~cm}$ (femenino); 74,89 $\pm 10,81 \mathrm{~kg}$ (masculino), $57,56 \pm 8,61 \mathrm{~kg}$ (femenino). Mientras que en el brazo dominante este ángulo fue como en los hombres $9,77^{\circ} \pm 2,82^{\circ}$ y $13,94^{\circ} \pm 3,97^{\circ}$ en las mujeres. El valor medio del ángulo de transporte en el brazo no dominante en los hombres fue de $9,85^{\circ} \pm 2,95^{\circ}$ y de $14,03^{\circ} \pm$ $4,08^{\circ}$ en las mujeres. El ángulo medio de desplazamiento fue de $9,81^{\circ}$ $\pm 2,82^{\circ}$ en hombres y $13,99^{\circ} \pm 3,97^{\circ}$ en mujeres. Hay una relación lineal entre el ángulo de desplazamiento y la altura $(r=-0,474, p$ $<0,001$, diámetro bi-acromial $(\mathrm{r}=-0,490, \mathrm{p}<0,001)$, diámetro biacromial / diámetro bi-trocantérico $(\mathrm{r}=-0,449, \mathrm{p}<0,001)$, longitud del antebrazo $(r=-0,366, p<0,001)$ y longitud del brazo $(r=-0,273$, $\mathrm{p}<0,001)$. Creemos que los valores de referencia del ángulo de carga ayudarán al clínico en el manejo de los desplazamientos del codo, las fracturas, el diseño protésico y el diagnóstico de enfermedades epicondilares.

PALABRAS CLAVE: Ángulo de desplazamiento; Articulación del codo; Diámetro bi-acromial / diámetro bitrocantérico; Longitud del antebrazo; Longitud del brazo.

\section{REFERENCES}

Allouh, M. Z.; Abu Ghaida, J. H.; Jarrar, A. A.; Khasawneh, R. R.; Mustafa, A. G. \& Bashaireh, K. M. The carrying angle: racial differences and relevance to inter-epicondylar distance of the humerus. Folia Morphol. (Warsz.), 75(3):388-92, 2016.

Atkinson, W. B. \& Elftman, H. The carrying angle of the human arm as a secondary sex character. Anat. Rec., 91(1):49-52, 1945.

Balasubramanian, P.; Madhuri, V. \& Muliyil, J. Carrying angle in children: a normative study. J. Pediatr. Orthop. B, 15(1):37-40, 2006.

Baskar, S. \& Kumar, S. Variations in carrying angle between two sexes on complete extension. J. Pharm. Sci. Res., 5(12):269, 2013.

Braune, W. \& Kyrklund. Cubitus valgus. Arch. Anat. Physiol., S:321, 1879.

Chang, C. W.; Wang, Y. C. \& Chu, C. H. Increased carrying angle is a risk factor for nontraumatic ulnar neuropathy at the elbow. Clin. Orthop. Relat. Res., 466(9):2190-5, 2008.

Dey, S.; Mandal, L.; Kundu, B.; Mondal, M. \& Sett, T. K. Carrying angle of the Elbow: It's changes from childhood to adulthood: Morphometric study in Eastern India. Indian J. Basic Appl. Med. Res., 8(2):823-30, 2013.

Emami, M.; Abdinejad, F.; Khodabkhshi, S.; Amini, M. \& Naseri, B. The normal carrying angle of the elbow in Shiraz. Med. J. Islam. Repub. Iran, 12(1):37-9, 1998.

Hassan, D.; Hossein, S.; Rahmani, P. \& Hossein, N. S. The study of predictor's anthropometric parameters of upper limb with elbow carrying angle in athletes. Sports Med. J., 10(4):2447-51, 2014.
Kothapalli, J.; Murudkar, P. H. \& Seerla, L. D. The carrying angle of elbowa correlative and comparative study. Int. J. Curr. Res. Rev., 5(7):71, 2013.

Kumar, B.; Pai, S.; Ray, B.; Mishra, S.; K. S. S.; Pandey, A. K. \& S. B. Radiographic study of carrying angle and morphometry of skeletal elements of human elbow. Rom. J. Morphol. Embryol., 51(3):521-6, 2010.

Lim, V.; Jacob, N. A.; Ghani, M. F. S.; Wang, D. L. C. \& Devi, K. A. An anthropometric study on the carrying angle of elbow among young adults of various ethinicities in Malaysia. Natl. J. Integr. Res. Med., 5(6):20-3, 2014.

Mall, F. P. On the angle of the elbow. Am. J. Anat., 4(4):391-404, 1905.

Paraskevas, G.; Papadopoulos, A.; Papaziogas, B.; Spanidou, S.; Argiriadou, H. \& Gigis, J. Study of the carrying angle of the human elbow joint in full extension: a morphometric analysis. Surg. Radiol. Anat., 26(1):1923, 2004.

Park, S. \& Kim, E. Estimation of carrying angle based on CT images in preoperative surgical planning for cubitus deformities. Acta Med. Okayama, 63(6):359-65, 2009.

Potter, H. P. The obliquity of the arm of the female in extension. The relation of the forearm with the upper arm in flexion. J. Anat. Physiol., 29(Pt. 4):488-91, 1895.

Rajesh, B.; Reshma, V. R.; Jaene, R. C.; Somasekhar, I. T. \& Vaithilingam, A. An evaluation of the carrying angle of the elbow joint in adolescents. Int. J. Med. Biomed. Res., 2(3) :221-25, 2013.

Ruparelia, S.; Patel, S.; Zalawadia, A.; Shah, S. \& Patel, S. V. Study of carrying angle and its correlation with various parameters. Natl. J. Integr. Res. Med., 1(3):28-32, 2010.

Sharma, K.; Mansur, D. I.; Khanal, K. \& Haque, M. K. Variation of carrying angle with age, sex, height and special reference to side. Kathmandu Univ. Med. J. (K. U. M. J.), 11(44):315-8, 2015.

Sönmez, M.; Tattemur, Y.; Karacan, K. \& Erdal, M. The relationship between carrying angle and distal extend of 2nd and 4th fingertips. Folia Morphol. (Warsz.), 71(3):173-7, 2012.

Srivastava, A. K. \& Solanki, S. Comparative study of goniometric and radiographic carrying angle in human. Int. J. Sci. Res, 4(2):292-4, 2015.

Terra, B. B.; Silva, B. C. M.; Carvalho, H. B. F.; Dobashi, E. T.; Pinto, J. A. \& Ishida, A. Evolution of the carrying angle of the elbow: a clinical and radiographic study. Acta Ortop. Bras., 19(2):79-82, 2011.

Van Roy, P.; Baeyens, J. P., Fauvart, D.; Lanssiers, R. \& Clarijs, J. P. Arthrokinematics of the elbow: study of the carrying angle. Ergonomics, 48(1114):1645-56, 2005.

Yilmaz, E.; Karakurt, L.; Belhan, O.; Bulut, M.; Serin, E. \& Avci, M. Variation of carrying angle with age, sex, and special reference to side. Orthopedics, 28(11):1360-3, 2005.

Zampagni, M. L.; Casino, D.; Martelli, S.; Visani, A. \& Marcacci, M. A protocol for clinical evaluation of the carrying angle of the elbow by anatomic landmarks. J. Shoulder Elbow Surg., 17(1):106-12, 2008.

Corresponding author:

Prof. Dr. Pınar Göker, M.D.

Çukurova University

Faculty of Medicine

Department of Anatomy 01330

Adana

TURKEY

\section{E-mail: pkarakas@cu.edu.tr}

Received: 02-06-2017

Accepted: $30-09-2017$ 